\title{
Prosthetic Joint Infection Caused by Gardnerella vaginalis: Case Report and Review of the Literature
}

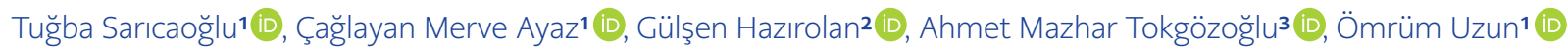 \\ 1 Department of Infectious Diseases and Clinical Microbiology, Hacettepe University School of Medicine, Ankara, Turkey \\ 2 Department of Medical Microbiology, Hacettepe University School of Medicine, Ankara, Turkey \\ 3 Department of Orthopedics and Traumatology, Hacettepe University School of Medicine, Ankara, Turkey
}

\begin{abstract}
Prosthetic joint infection is not uncommon, but Gardnerella vaginalis has been reported rarely as a causative agent. A 45-year-old patient with no remarkable history was admitted to the hospital ten months after total hip replacement because of loosening of the prosthesis. Initial culture grew S. anginosus. Repeated culture of the debridement material grew G. vaginalis. After adequate and effective treatment, he was discharged in good health. This is the first case of a male patient with prosthetic joint infection caused by G. vaginalis. This pathogen should be considered in the presence of slow-growing, gram-variable rods in culture.
\end{abstract}

Keywords: Prosthetic joint infection, Gardnerella vaginalis, immunocompetent male

\section{INTRODUCTION}

G ardnerella vaginalis is a facultative anaerobic, gram-variable pleomorphic rod that has been associated with bacterial vaginosis (BV). Extra-vaginal infections caused by $G$. vaginalis are uncommon. We present a unique case of prosthetic joint infection with $G$. vaginalis in a man and discuss it with three more cases reported in the literature.

\section{CASE PRESENTATION}

A 45-year-old male was consulted to the Department of Infectious Diseases for probable prosthetic hip infection. He had a femoral neck fracture of the left femur and was treated with internal fixation in another medical center. Nine months later, he was re-admitted because of pain and limitation of movement of the left hip. He underwent a cementless total hip replacement. Ten months after surgery, the prosthetic hip dislocated and
Corresponding Author:

Tuğba Sarıcaoğlu

E-mail:

tugbasarica5@gmail.com

Received: September 12, 2021

Accepted: December 13, 2021

Published: February 14, 2022

Suggested citation:

Sarıcaoğlu T, Ayaz ÇM, Hazırolan G, Tokgözoğlu AM, Uzun

Ö. Prosthetic joint infection caused by Gardnerella vaginalis: Case report and review of the literatüre. Infect Dis Clin Microbiol. 2022; 1.

DOI: $10.36519 /$ idcm.2022.92 
a closed reduction was performed. Because of repeating dislocation in two days, he was referred to the Department of Othopedics and Traumatology in our hospital. His initial vital signs were normal.

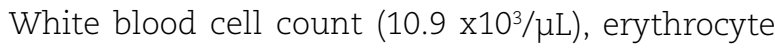
sedimentation rate $(70 \mathrm{~mm} / \mathrm{h}$, normal: $<20 \mathrm{~mm} / \mathrm{h})$ and C-reactive protein levels $(1.33 \mathrm{mg} / \mathrm{dL}$, normal range: $0-0.8 \mathrm{mg} / \mathrm{dL}$ ) were elevated.

The hip was revised with a modular cementless femoral stem and a cementless constrained cup was used to revise the acetabulum to prevent a re-dislocation. Intraoperative tissue cultures grew bacterial colonies identified as Streptococcus anginosus by matrix-assisted laser desorption ionization-time of flight mass spectrometry (MALDI-TOF MS). Specimens obtained from tissue biopsy were consistent with an infection. Intravenous ceftriaxone treatment was started. One week later, the patient's hip pain intensified, followed by swelling and purulent discharge from the incision and an increase in CRP levels to $10 \mathrm{mg} / \mathrm{dl}$. Extensive inflammation was detected with significant fluid collection in repeat surgery. Four tissue cultures were obtained during these debridement procedures under sterile conditions. Tissue cultures were performed on a MacConkey II agar / Columbia CNA agar with 5\% sheep blood (BD, USA), chocolate agar (BD, USA) and thioglycolate broth. After one night of incubation at $37^{\circ} \mathrm{C}$ under aerobic conditions with $5 \% \mathrm{CO} 2$, both alpha-hemolytic, transparent and lactose negative colonies were observed. Isolates were identified with conventional tests and MALDI-TOF MS. One of the culture plates contained both catalase and oxidase negative gram-negative to gram-variable bacilli and catalase-positive and oxidase-negative gram-negative bacilli. Isolates were identified as G. vaginalis and Acinetobacter calcoaceticus-baumannii complex with scores $\geq 2.0$; accurate identification was performed to the species level by MALDI-TOF MS. On the twentieth day of ceftriaxone treatment, colistin (110 mg b.i.d) and clindamycin (900 mg t.i.d.) were added. Urine analysis was normal, and urine culture was negative. Urinary sexually transmitted diseases (STD) panel and samples obtained with a urethral swab were also negative. After three months of antibiotic treatment, the patient's clinical symptoms improved. CRP levels decreased to $0.69 \mathrm{mg} / \mathrm{dl}$ with normal WBC $\left(7.1 \times 10^{\wedge} 3 / \mu \mathrm{L}\right)$, normal sedimentation rate $(18 \mathrm{~mm} / \mathrm{h})$. The follow-up magnetic resonance imaging showed a marked decrease in periprosthetic inflammation.

\section{DISCUSSION}

To our knowledge, this is the first male patient, and the fourth case with prosthetic joint infection caused by $G$. vaginalis reported in the literature (Table 1). Extra-vaginal infections caused by this pathogen are uncommon, bone and joint infections are even rarer. This may be because of the low virulence of the organism as well as difficulty in identification.

G. vaginalis has a number of virulence factors such as biofilm formation, production of sialidase $\mathrm{A}$ and a toxin (vaginolysin) $(1,2)$. Extra-genital infections with this organism have been reported uncommonly in patients with a variety of risk factors, i.e.,

Table 1. Cases of prosthetic joint infections caused by Gardnerella vaginalis in the literature.

\begin{tabular}{|c|c|c|c|c|c|c|c|c|}
\hline Case reports & Age & Gender & Lesion & $\begin{array}{l}\text { Time after } \\
\text { implant }\end{array}$ & Dx & $\begin{array}{c}\text { Surgical } \\
\text { management }\end{array}$ & Antibiotic treatment & Outcome \\
\hline Hoarau G, et al. (6) & 71 & Female & $\begin{array}{l}\text { Right hip } \\
\text { prosthesis }\end{array}$ & 10 years & $\begin{array}{c}\text { Intraop sample culture } \\
\text { and gene amplification \& } \\
\text { sequencing }\end{array}$ & $\begin{array}{l}\text { One-stage surgical } \\
\text { replacement }\end{array}$ & $\begin{array}{l}\text { TMP-SMX plus rifampin } \\
\text { for } 3 \text { months }\end{array}$ & Cure \\
\hline Thomas M, et al. (14) & 68 & Female & $\begin{array}{l}\text { Right hip } \\
\text { prosthesis }\end{array}$ & 10 years & $\begin{array}{l}\text { Hip aspirate culture and } \\
\text { MALDI-TOF MS }\end{array}$ & $\begin{array}{l}\text { One-stage surgical } \\
\text { replacement }\end{array}$ & $\begin{array}{l}\text { Clindamycin } 10 \text { days, } \\
\text { switched to amoxicillin } \\
\text { for } 8 \text { weeks }\end{array}$ & Cure \\
\hline Thomas M, et al. (14) & 32 & Female & $\begin{array}{l}\text { Left hip } \\
\text { prosthesis }\end{array}$ & 10 years & $\begin{array}{l}\text { Hip aspirate culture and } \\
\text { MALDI-TOF MS }\end{array}$ & $\begin{array}{l}\text { One-stage surgical } \\
\text { replacement }\end{array}$ & $\begin{array}{c}\text { Clindamycin for } 12 \\
\text { weeks }\end{array}$ & Cure \\
\hline Present report & 45 & Male & $\begin{array}{l}\text { Left hip } \\
\text { prosthesis }\end{array}$ & 19 months & $\begin{array}{c}\text { Intraop tissue culture and } \\
\text { MALDI-TOF MS }\end{array}$ & $\begin{array}{l}\text { Debridement and } \\
\text { retention }\end{array}$ & $\begin{array}{c}\text { Clindamycin for } 12 \\
\text { weeks }\end{array}$ & Cure \\
\hline
\end{tabular}


immunosuppression, anatomical genitourinary abnormalities, surgical operation, nephrolithiasis or urolithiasis, urethral stricture, immunosuppressive therapy, chronic alcoholism and intravenous drug use $(3,4)$. A few patients have been described with no underlying factor (4-6).

The majority of patients with extra-vaginal infection are women. G. vaginalis is described as a component of normal vaginal flora. While the microorganism may reach the urinary tract via ascending route to cause a peri-nephric abscess (7), hematogenous spread from the vagina has also been implicated in female patients with extra-genital infection. A few male patients have been described with infective endocarditis (8), sepsis, perinephric abscess $(7,9)$, and pulmonary infection $(3,10)$. It is postulated that colonization of the male urethra $(4.5 \%$ to $11.4 \%)(11,12)$ or rectal mucosa in men who have sex with men (up to 83.2\%) (13) precedes hematogenous spread.

G. vaginalis has been shown to form biofilm on contraceptive intravaginal ring, but there is no study on extra-vaginal foreign bodies. Infections in all three women were late-onset (10 years), and G. vaginalis were detected in the vaginal flora of two patients (14). Bacteremia with subsequent seeding of the prosthesis was implicated in all three cases. In our patient, we could detect neither G. vaginalis nor other potential STD pathogens in urethral samples. We did not check the rectal mucosa for colonization. When questioned again, the patient did not provide further information about his sexual practice other than being married and not having another sexual partner.
Interestingly, the initial intraoperative cultures grew only S. anginosis, and antimicrobial treatment was started accordingly. S. anginosus is ubiquitous in the body, normally colonizing the upper respiratory, digestive and reproductive tracts. A recent case study was reported a 61-year-old woman with vertebral osteomyelitis caused by G. vaginalis plus Streptococcus parasanguinis (15). In our patient, it was suggested that transient bacteremia after an episode of dysuria following the sexual activity could explain the pathogenesis. We believe our patient had a polymicrobial infection but $G$. vaginalis could not be detected initially. The growth of A. baumannii was detected subsequently and considered acquired in the hospital during invasive procedures.

G. vaginalis is susceptible to several antibiotics, including penicillin, vancomycin, clindamycin and metronidazole. There are limited data on the treatment of extra-vaginal infections with metronidazole. The three patients with prosthetic joint infections reported previously were treated with clindamycin. Our patient received clindamycin for G. vaginalis and colistin for A. baumannii for three months with a successful outcome.

\section{CONCLUSION}

In the presence of slow-growing, gram-variable rods in cultures, even in individuals without the urogenital disease, G. vaginalis should be considered. Further studies are needed to understand the pathogenesis and optimal treatment of extra-vaginal $G$. vaginalis infections.

\section{Ethical Approval: N.A.}

Informed Consent: Written informed consent was obtained from the patient to publish this case report and accompanying images.

Peer-review: Externally peer-reviewed

Author Contributions: Concept - T.S., Ç.M.A., Ö.U.; Design - T.S., Ç.M.A., Ö.U.; Supervision - T.S., Ç.M.A., G.H., A.M.T., Ö.U.; Fundings
- T.S., Ö.U.; Data Collection and/or Processing - T.S., Ç.M.A., G.H., Ö.U.; Analysis and/or Interpretation - T.S., Ö.U.; Literature Review - T.S., Ç.M.A., Ö.U.; Writer - T.S., Ç.M.A., Ö.U., G.H., A.M.T.; Critical Reviews - T.S., Ç.M.A., Ö.U., G.H., A.M.T.

Conflict of Interest: The authors declare no conflict of interest.

Financial Disclosure: The authors declared that this study has received no financial support. 


\section{REFERENCES}

1 Swidsinski A, Doerffel Y, Loening-Baucke V, Swidsinski S, Verstraelen $\mathrm{H}$, Vaneechoutte M, et al. Gardnerella biofilm involves females and males and is transmitted sexually. Gynecol Obstet Invest. 2010;70(4):256-63. (CrossRef)

2 Schwebke JR, Muzny CA, Josey WE. Role of Gardnerella vaginalis in the pathogenesis of bacterial vaginosis: a conceptual model. J Infect Dis. 2014;210(3):338-43. (CrossRef)

3 Legrand JC, Alewaeters A, Leenaerts L, Gilbert P, Labbe M, Glupczynski Y. Gardnerella vaginalis bacteremia from pulmonary abscess in a male alcohol abuser. J Clin Microbiol. 1989;27(5):1132-4. (CrossRef)

4 Bekasiak A, Dammann F, Nader C. A rare cause of a scrotal abscess due to the symbiotic infection of Gardnerella vaginalis and Prevotella bivia in an adult male. Pathogens. 2020;9(2):93. (CrossRef)

5 Graham S, Howes C, Dunsmuir R, Sandoe J. Vertebral osteomyelitis and discitis due to Gardnerella vaginalis. J Med Microbiol. 2009;58(Pt 10):1382-4. (CrossRef)

6 Hoarau G, Bernard S, Pavese P, Saragaglia D, Croize J, Maurin M. Gardnerella vaginalis as a rare cause of prosthetic joint infection. J Clin Microbiol. 2012;50(12):4154-6. (CrossRef)

7 Finkelhor RS, Wolinsky E, Kim CH, Tchou P, Frengley JD. Gardnerella vaginalis perinephric abscess in a transplanted kidney. $\mathrm{N}$ Engl J Med. 1981;304(14):846. (CrossRef)

8 Yoon HJ, Chun J, Kim JH, Kang SS, Na DJ. Gardnerella vaginalis septicaemia with pyelonephritis, infective endocarditis and septic emboli in the kidney and brain of an adult male. Int $\mathrm{J}$ STD AIDS. 2010;21(9):653-7. (CrossRef)
9 Calvert LD, Collins M, Bateman JR. Multiple abscesses caused by Gardnerella vaginalis in an immunocompetent man. J Infect. 2005;51(2):E27-9. (CrossRef)

10 Bittar JM, Gazzetta J. Gardnerella vaginalis causing pulmonary infection in a young adult: A novel case. Respir Med Case Rep. 2019;28:100916. (CrossRef)

11 Josephson S, Thomason J, Sturino K, Zabransky R, Williams J. Gardnerella vaginalis in the urinary tract: incidence and significance in a hospital population. Obstet Gynecol. 1988;71(2):24550.

12 Dawson SG, Ison CA, Csonka G, Easmon CS. Male carriage of Gardnerella vaginalis. Br J Vener Dis. 1982;58(4):243-5. (CrossRef)

13 Cox C, Watt AP, McKenna JP, et al. Gardnerella vaginalis and Mollicute detection in rectal swabs from men who have sex with men. Int J STD AIDS. 2017;28(7):708-14. (CrossRef)

14 Thomas M, Zeller V, Heym B, Meyssonnier V, Marmor S, Ziza JM. Gardnerella vaginalis, from the vaginal microbiota to prosthetic joint infection. J Bone Jt Infect. 2019;4(4):189-93. (CrossRef)

15 Kim JJ, de Castro Junior RL, Schauer M, Bauler LD. Rare case of osteomyelitis caused by Gardnerella vaginalis and Streptococcus parasanguinis in a postmenopausal woman. BMJ Case Rep. 2021;14(2):e237611. (CrossRef) 